\title{
The Problems With American Exceptionalism
}

In 2001, German President Johannes Rau made a statement that divided Germany. In an interview with a television station, Rau said that although he is "pleased and grateful" to be German, he cannot be "proud" of it--as "it is not an achievement to be German, [but] just a matter of luck." This statement drew criticism from the opposition in Germany who claimed that without patriotism, it is not possible to adequately represent the interests of the country. Many politicians called for Rau's resignation or, at the very least, a recant of his words--he did neither. The uproar died down shortly after, and Rau served as President for another three years.

After President Rau's death in 2006, most This comparison between President

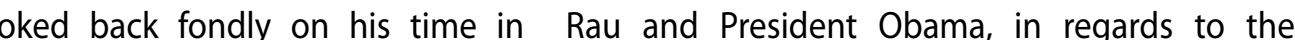
office. An obituary in The Times claimed "he was a issue of national pride, serves as evidence powerful presence who remained popular...and that Americans are more willing than other tempered any outbreak of nationalist arrogance" 2 countries' citizens to tout their nation's supposed

A year after Rau's death, in America, greatness and proclaim that it is "exceptional". Barack Obama faced criticism for not wearing The notion of American exceptionalism, which an American flag pin on his lapel during the is interchangeable with American superiority, Democratic primary. In similarity to Rau's is often embraced and glorified by Presidential controversial statement, Obama's critics said that candidates who vie to be the so-called "leader his lack of patriotism made him unfit for office. of the free world." In order to gain support, these

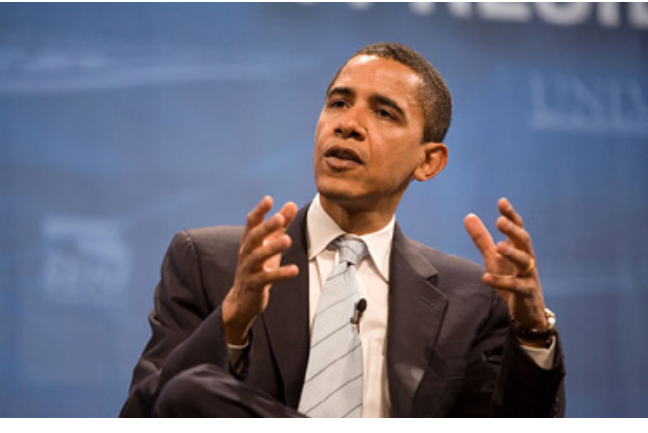

Presdient Barack Obama spekaing without a flag pin.

However, unlike Rau, after Obama attained the Democratic nomination for President, he went against his initial position and began to wear a flag pin. It is unclear whether Obama's new stance, was actually driven by a true change of heart on the issue, or simply by a strategy to gain more votes. However, Obama's patriotism was evident during last January's State of the Union Address, where he called America, "not just a place on a map, but the light to the world." exceptional country. Without a consensus over the criteria required to judge whether a country is considered exceptional or not, there is no evidence to suggest that the belief of American exceptionalism holds true. In this paper, I will analyze why America is not an exceptional nation. Subsequently, I will talk about why Americans' exceptionalist view hinders progress at home and hurts their relations abroad.

First, it should be noted that when the word exceptionalism is used to describe America, it is not used to refer to America as unique or different from other nations, but rather as being more eminent and esteemed than other nations. Although Alexis de Tocqueville--the first academic to describe the United States as exceptional-originally used the term to emphasize how America was different from other Western nations, the modern view of American exceptionalism is something completely different.

As Stephen M. Walt puts it, American exceptionalism today is the "self-congratulatory" belief that America is the world's superpower and is "worthy of universal admiration." ${ }^{4}$ New Jersey Governor Chris Christie's (R-NJ) recent words at the Ronald Reagan library are a prime example of this modern view of American exceptionalism. In his speech, Christie not only called Americans "better" than other countries' citizens, but also proclaimed that the US is "a beacon of hope for the world."

This modern interpretation of American exceptionalism has bipartisan backing with President Obama's 2009 speech during the celebration of NATO's $60^{\text {th }}$ anniversary serving as evidence. He said the following:

"I believe in American exceptionalism, just as I suspect that the Brits believe in British exceptionalism and the Greeks believe in Greek exceptionalism. I am enormously proud of my country and its role and history in the world. If you think about the site of this summit and what it means, I don't think America should be embarrassed to see evidence of the sacrifices of our troops, the enormous amount of resources that were put into Europe postwar, and our leadership in crafting an alliance that ultimately led to the unification of Europe. We should take great pride in that.
And if you think of our current situation, the United States remains the largest economy in the world. We have unmatched military capability. And I think that we have a core set of values that are enshrined in our Constitution, in our body of law, in our democratic practices, in our belief in free speech and equality that, though imperfect are exceptional."

These words, along with Robert Schlesinger'sof US News and World Report--discovery that President Obama is "the only President in the last 82 years who has publicly uttered the phrase 'American exceptionalism,"'7 prove that the notion of "American exceptionalism" is prevalent in the present age.

However, just because the idea of America's superiority is talked about today does not mean that it is true. It could be argued that De Tocqueville and others have been successful in pointing out America's uniqueness--through discussion of its absence of feudalism, its puritanical roots, or the fact that it was a nation built on an idea. ${ }^{8}$ However, when the discussion moves from uniqueness to superiority, a problem arises. If one is going to argue that a country is better, or more important than another country, then there needs to be criteria to decide this superiority.

For example, if it was decided that the best country in the world is the one with the best education system, South Korea would take the crown as its students scored the highest on the Organization for Economic Co-operation and Development's (OECD) multi-subject tests last year. The US, on the other hand, finished fourteenth. ${ }^{9}$ Thus, establishing criteria for judging is a vital aspect for determining superiority, as any country can essentially be considered the best as long as the criteria suits its strengths.

It is for this reason that most arguments in favor of the modern view of "American exceptionalism" never go very far: there is no universal consensus on how countries are to be judged. It is all relative to the one who chooses the assessment criteria.

In fact, if an objective third party were to 
then the US would not be categorized as a superior country, but rather as one in steep decline. King's College London recently released a study claiming the US not only has the highest incarceration rate in the world, but that this rate has quadrupled since $1980 .{ }^{10}$ The fact that the US prison population rises each year, while other countries--such as the Netherlands ${ }^{11}$-- are having to close down prisons due to lack of crime, does not put America in a favorable light when discussing its standing in the world. Moreover, according to a 2008 study by the Centers for Disease Control and Prevention (CDC) the infant mortality rate in the US is growing in relation to that of other countries. America had the $23^{\text {rd }}$ lowest infant mortality rate in 1990 , but dropped to $34^{\text {th }}$ place in $2008 .^{12}$

However, one cannot define a country through one statistic alone, as one has to consider many different ways of measuring achievement before making an unbiased list of the most successful countries in the world. In 2010 Newsweek undertook such a task as the magazine used the criteria of health, economic dynamism-defined as a country's economic openness and the breadth of its corporate sector--education political environment, and quality of life..$^{13}$ The list also took into account the income and size of the countries evaluated. In the overall rankings, the US finished eleventh. It did not finish number one in any of the categories--its only top-ten rankings were in economic dynamism and quality of life.

Of course, this is just one study, but these comparisons and statistics suggest the decline of America's superiority over time. Though only the current president has uttered the phrase "American exceptionalism", it seems that presentday Americans should now, more than ever, reevaluate their status in the world. Americans need to understand that much improvement has to be done, if they truly want to be considered as exceptional. Thus, present-day claims of exceptionalism are unfounded.

Although many Americans may be willing to admit that their nation is exceptional, they do not take into account the consequences that such a self-important view can have. In regards to domestic affairs, when American politicians proclaim that their country is exceptional, they are thus suggesting that US policies are the best and that other nations' are inferior. With this mindset of US dominance, there is harsh reaction from Americans whenever there is even a mention of possibly adopting European-type healthcare or education reform. It does not matter if these countries' systems are consistently ranked better than America's, or that their adoption could possibly improve the average American's daily life, as anything other than the US's way is considered to be subordinate. ${ }^{14}$

Outside of domestic governance, viewing the US as exceptional can also have grave consequences when it comes to foreign policy. This is the case because the belief of American exceptionalism is also linked with the principle of unilateralism--the doctrine that a country should be able to do an action for its own good, even if its action has international opposition. American exceptionalism and unilateralism suggest that since the US is the most important nation in the world, it should be exempt from global treaties, while having certain powers that other nations do not. Proponents of unilateralism, who Maria Ryan claims are mostly neoconservatives, may argue that since the US has great economic and military power, it should be allowed to act independently of other international factors. ${ }^{15}$ However, this philosophy has many negative outcomes.

Though the US is not an "exceptional" country in terms of superiority, it is still a nation with a famous historical reputation. Also, as Daniel Deudney and Jeffrey Meiser point out, due to the fact that it is the country with the largest economy and military defense, it is very influential on the global stage. ${ }^{16}$ This power is the reason why when the American government commits a global act unilaterally, and outright rejects multilateral organizations, it calls the legitimacy of such multilateral organizations into question. An example of this phenomenon is when the US government went to war with Iraq in 2003. Multilateral organizations, such as NATO and the United Nations--both of which are mostly made up of American allies--did not support the proposed invasion of Iraq, but the US disregarded their opinions and went to war anyway. Kofi Annan--the United Nations Secretary-General at the time--said the war in Iraq violated the UN Charter, designed to achieve international cooperation, and that all UN members are bound to follow. In spite of this, the UN never formally punished the US government for violating the Charter, and to this date, the US still has troops in Iraq. ${ }^{17}$

The United States' unilateral act was dangerous precedent because it challenged the UN's authority with regards to international law: it made it so that other nations can use the Iraq war as an exemplar for why they should be able to

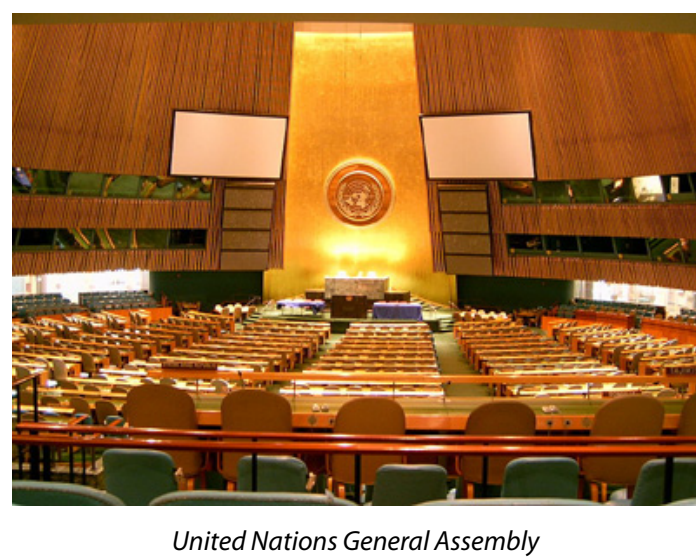

go to war without the UN or NATO's approval. In going against the UN and NATO--two multilateral organizations designed to promote world stability--the US is essentially implying that the decision to go to war should be a country's decision alone, and that an international consensus is no longer needed. If a smaller, less influentia country--such as North Korea in 200918--had violated the UN charter and committed military actions despite international objections, then that country would have been imposed with sanctions. However, even though both America and North Korea violated the UN Charter, the US didn't face any punishment because of its influential role in global politics.

The US has also rejected the Ottawa Treaty. This multilateral agreement--signed by 157 different countries--bans the use and further development of landmines. The US has not signed the treaty despite the fact that it owns one of the largest landmine arsenals in the world. ${ }^{19}$ By not signing the Ottawa Treaty, which protects not only soldiers but civilians as well, the US runs the risk of portraying itself as uncooperative in the promotion of world peace. Not many agreements have more international backing than the Kyoto Protocol and the Ottawa Treaty, which suggests that most countries believe they provide worldwide benefits. The US, by choosing not to sign these popular treaties for whatever reason, is thus taking a stance that favors its own interests instead of supporting a global compromise.

This lack of international cooperation, supposedly justified by America's so-called "exceptional" status, has irritated other countries' citizens who reject the notion of a world dominated by the US Kim Campbell--the former Prime Minister of Canada--noted her irritation with the idea of US superiority in an interview last January. ${ }^{20}$ When asked how people from other countries view the idea of American exceptionalism, her response was, "dimly."21 While the people of the US are free to believe that their country is "exceptional," they have to understand that the perception of such a status is not for them to choose. American politicians may tout American exceptionalism and incorporate its ideology into domestic policies.

Nevertheless, they cannot claim what Governor Christie did: other nations "aspire to be" the US if foreign opinion is to the contrary. Even though the US plays an influential and important role in global politics, Campbell's response provides evidence supporting the notion that American superiority is solely an American idea.

If the US were truly looked upon as being an "exceptional" nation, then the UN and NATO would not have opposed the invasion of Iraq in 2003. American allies who did not go to Iraq-France, Germany, and Turkey--probably would have followed the US, and would have participated in the War out of fear that if they did not, then they would lose an alliance with a superior nation. If the US were actually an exceptional country, then the Kyoto Protocol and the Ottawa Treaty would not be effective or have respected legitimacy among the international community since they do not have US involvement. If other countries actually 
did view the US as superior, then they would attempt to mimic American domestic policies, such as health care. However, it is the other way around. In March of 2010, after President Obama passed his healthcare reform bill, French President Nicolas Sarkozy -- addressing Columbia University students in New York -- said, "Welcome to the club of states who don't turn their back on the sick and the poor."22 Sarkozy's claim shows that, at least in some respects, US policies are not seen with the same enthusiasm abroad that they are met with at home. ${ }^{23}$

It is not only foreign heads of state that will not adhere to the idea of American superiority, as many foreign citizens do so as well. Several weeks before the proposed invasion of Iraq-February 15, 2003--an estimated six to ten million people, in sixty different countries, expressed their opposition to the United States' foreign policy. ${ }^{24}$ This global opposition to the war showed that there are millions of international citizens who reject the notion of American exceptionalism. ${ }^{25}$ If these foreigners did accept the view that America

Excessive national pride ... causes arrogance and makes people

believe that one's nation is exempt from established ethical norms.

is exceptional, then they would have allowed the US to do as it wished instead of voicing disapproval for the nation's unilateral actions. Even though the US went to war with Iraq--in spite of tremendous international objection--this action still does not support the view of American eminence.

In October of 2011, President Obama announced that virtually all US troops will withdraw from Iraq by the end of the year. In the eight years between the start of the invasion and this announcement, 54 different countries have officially condemned the US for its actions in Iraq While many of these nations were against the war from the beginning, one of its main initial foreign supporters, Tony Blair--the former Prime Minister of the United Kingdom--publicly expressed "regret" in regards to the invasion at Britain's public to strengthen the bonds between nations, not weaken them.

Though President Obama is noted for being the only President to publicly use the phrase "American exceptionalism," he raised an important point on the matter later on in his 2009 speech for NATO's $60^{\text {th }}$ anniversary:

"Now, the fact that I am very proud of my country and I think that we've got a whole lot to offer the world does not lessen my interest in recognizing the value and wonderful qualities of other countries, or recognizing that we're not always going to be right, or that other people may have good ideas, or that in order for us to work collectively, all parties have to compromise and that includes us.

\section{Endnotes}

"President not'proud' to be German." BBC News, 20 March, 2001

2006

Friedman, Thomas L. \& Mandelbaum, Michael. "America Really Was That Great." Foreign Policy, November 2011.

Walt, Stephen M. "The Myth of American Exceptionalism." Foreign Policy, November 2011.

Christie, Chris. Keynote Address at Reagan Library. Speech given at The Ronald Reagan Presidential Library, 27 September, 2011.

Benen, Steve. "American Exceptionalism." Washington Monthly, 5 April 2009.

Schlesinger, Robert. "Obama Has Mentioned Exceptionalism More Than Bush." US News and World Report, 31 Jan. 2011.

See supra note 3 .

Shepherd, Jessica. "World education rankings: which country does best at reading, maths and science?" guardian.co.uk, 7 Dec. 2010

$10 \mathrm{http}: / /$ www.kcl.ac.uk/depsta/law/research/icps/worldbrief/wpb_stats.php?area=all\&category=wb_poprate.>.

"CDC Releases New Infant Mortality Data." Centers for Disease Control an

"Ameris exceptionalism: Political fury, paralysis, and other people's solutions." The Economist, 12 September, 2011.

15 Ryan,

. Deudney, Daniel and Meiser, Jeffrey. "American exceptionalism." United States Foreign Policy (2008).

"raq war illegal, says Annan." BBC News, 16 Sept. 2004.

18 Kellerhals, Merle. "United Nations Imposes Sanctions on North Korea." America.gov, 12 June 2009.

Landmine \& Cluster Munition Monitor. < http://www.the-monitor.org/index.php/publications/display?url=Im/2004/usa.html.>.

See supra note 4.

"Real Time with Bill Maher." HBO, 28 Jan. 2011

Drum, Kevin. "Quote of the Day: Sarkozy on Healthcare" Mother Jones 29 March 2010.

See supra note 4.

"Millions join global anti-war protests." BBC News, 17 Feb. 2003.

.

"Tony Blair'regrets' 'raq dead in Chilcot grilling." BBC.co.uk, 21 Jan. 2011.

27 See supra note 2

http://www.flickr.com/photos/worldeconomicforum/346750098/

http://commons.wikimedia.org/wiki/File:Barack_Obama_at_Las_Vegas_Presidential_Forum.jpg 